\title{
Covenantal Metaphors and Interreligious Reality
}

\author{
Alon Goshen-Gottstein \\ (The Elijah Interfaith Institute)
}

\section{The Covenant and its Metaphors}

There are many dimensions to doing philosophy, and theology. One does not typically consider metaphor a major part of doing theology. Yet, our religious thought is deeply conditioned by metaphors. Thomas Aquinas opens his Summa Theologica with a justification for the use of metaphors in theological thinking. Since God uses metaphors in sacred scripture, they must have a role in revelation and that "therefore this sacred science (theology) may use metaphors". ${ }^{1}$ It takes a particular theological mind to work constructively with metaphors, exploring them, applying them, bringing out their potential and, often hidden, implications. It requires a mind that is sensitive to literary subtleties, to beauty and form and to the ways in which these can be put in the service of a philosophical and theological quest. Such is the creative mind of Staszek Krajewski, as I have come to appreciate his contribution to interreligious relations and in particular to Jewish theology of religions. I have had the good fortune of working with him on several projects, including two of his contributions to edited volumes that I have put together. In conversation, in group dialogue and in the written form, I am time and gain impressed by the beauty of his mind and approach, a beauty that draws significantly on literary dimensions, and especially on how we apply metaphors to our theological thinking. His essay "Can Another Religion Be

\footnotetext{
Summa Theologica 1.1.9.
} 
Seen as the Other" applies creatively the metaphor of the priest, and Israel as the priestly nation, to a contemporary view of other religions. ${ }^{2} \mathrm{His}$ "Two Dimensions of Jewish Identity" builds on the metaphors of camp and congregation, developed by Rabbi Soloveitchik. ${ }^{3}$ I would therefore like to dedicate this essay to Staszek and reflect on the very phenomenon of working with metaphors to advance our theological thinking. I shall do so by tackling what may be Judaism's most basic metaphor and asking how it might be applied today, under changed historical and theological circumstances.

Covenant is a formative category of Jewish theology. Large parts of the Hebrew Bible frame Israel's relationship with God in terms of a covenant, and it is by far the most dominant conceptual tool for defining Israel's unique relationship with God. The notion of covenant itself is both literal and metaphorical. It is literal inasmuch as Israel enters a concrete covenantal relationship with God, following patterns of covenant-making, as these were current in the Ancient Near East, in defining moments such as the Sinai covenant. But the covenant is also metaphorical, inasmuch as it extends to the divine realm a relationship that was central to human relations in the Ancient Near East. Covenant was a central tool in ancient diplomacy, with nations making covenants with each other. It was also a tool for regulating social relations, between the king and his people, following a pattern of the vassal treaty. This reality is transposed to Israel's relationship with God.

This transposition finds expression through a series of metaphors. One of the most common biblical metaphors owes to the covenantal relationship. Israel as God's wife and the marriage metaphor as such grow on the soil of covenantal thinking. By means of this metaphor a love relationship can be expressed. It has been suggested that these covenantal foundations inform the rabbinic affirmation of the meaning and sanctity of the Song of Songs. ${ }^{4}$ The metaphor also informs the biblical view of a jealous God, who demands exclusive allegiance and cannot tolerate Israel's following of other gods. Underlying such application is a very literal view of marriage. Marriage, and likely love as well, belong between

In: A. Goshen-Gottstein, E. Korn (eds.), Jewish Theology and World Religions, Littman Library, Oxford 2012, pp. 137-147.

3 Scheduled to appear in: A. Goshen-Gottstein (ed.), Judaism's Challenge: Election, Divine Love and Human Enmity, Academic Studies Press, Boston 2020.

4 G. Cohen, The Song of Songs and the Jewish Religious Mentality, Jewish Theological Society, New York, 1966. 
exclusive partners. God has chosen only one people, whom he loves; Israel is expected to show similar fidelity. In the same way that on the earthly plane there are other potential lovers who could upset the stability of a faithful marriage, so on the metaphysical plane there are other gods or powers, following whom would upset the exclusive allegiance due to God. These powers are in all likelihood considered real, making the covenantal metaphor dependent on a polytheistic, or henotheistic, view.

There are other possible metaphors of the covenant. One such metaphor is that of king and nation, following the example of the Ancient Near Eastern vassal treaty. Entering a covenant with God is like the acceptance of His kingdom by his people. ${ }^{5}$ Again, "one king - one people" is the starting point. Each metaphor seeks to bring out a particular aspect of the relationship and therefore we may consider what the point of each metaphor is. If the marriage metaphor profiles love and loyalty, the peoplehood metaphor profiles commitment and dedication to follow the king and obey his rules.

It is worth noting that one important relational metaphor - that of God as father and Israel as son - is not related to the covenantal conceptual complex. The metaphor either expresses divine care and feeling or filial responsibilities, but is not directly associated with the covenantal complex. ${ }^{6}$ Some have suggested a reticence to apply the metaphor because of its pagan associations. ${ }^{7}$ The metaphor could suggest a natural biological relationship, rather than one born of a decision to commit, with a distinct historical starting point. I have suggested that the metaphor actually captures the same range of meaning as does the notion of covenant. Its contribution is emotional and literary, particularly in poetic contexts, and may therefore be less frequent precisely because it does not expand the conceptual range of the covenant. ${ }^{8}$

This metaphor is likely implicit in biblical thinking, but is made explicit in rabbinic literature. See Mechilta, Bahodesh 5. With the historical decline in covenantal thinking, the notion of acceptance of the yoke of divine kingdom took its place as a functional substitute. See Reuven Kimelman, The Shema' Liturgy: From Covenant Ceremony to Coronation, in: Kenishta: Studies of the Synagogue World, ed. J.Tabory, Bar Ilan University Press, 2001, pp. 9-105.

6 There is one single occurrence of the metaphor in conjunction with the covenant in Malachi 2,10 . The context is a social contract, in view of the one creating father. This does suggest that the metaphor is not incommensurate with covenantal thinking. See more below.

7 Th.C. Vriezen, Theologie des Alten Testaments in Grundzeugen, Wageningen, 1965, pp. 120-122.

8 A. Goshen-Gottstein, God and Israel and Father and Son in Tannaitic Literature, Phd, Hebrew University of Jerusalem, 1986, p. 221 [Hebrew]. 
Two further points are relevant for the appreciation of the biblical usage of covenant. The covenants described thus far build on the lack of symmetry or at least lack of hierarchy in a relationship. God is always the more powerful, higher positioned partner in the covenant, while Israel occupies the lesser role. Biblical thinking also knows of a more symmetrical covenant. Friendship is a form of covenant or rather can be captured and its commitments solidified through covenant. Exemplary is the covenant between David and Jonathan. ${ }^{9}$ Other biblical stories present this type of covenant among equals..$^{10}$

One final point, taking us back to the historical concreteness of covenants, is the biblical prohibition on making covenants with other, pagan, peoples. As part of the effort to maintain purity of faith and to avoid contamination of Israel's faith and its exclusive allegiance, the Torah prohibits making a covenant between Israel and the nations of Canaan. Such covenant implies recognition of their gods, or at least draws their gods into the relational orbit, by ensuring the existence of the people and their ways. The prohibition therefore seeks to safeguard covenantal purity and exclusivity, limiting relations with others in the framework of the covenant and its worldview. ${ }^{11}$

During the biblical period, covenant was the most central theological category by means of which Israel's relationship with God was expressed. ${ }^{12}$ Israel's unique standing and its exclusive relationship with God found expression by appeal to a political category of the day. Israel alone, of all the peoples of the Ancient Near East, expressed its relation to God by means of this legal and political category. The category provided definition for the mutual responsibilities of both parties, offered a definition for the relationship and established God as Israel's God, while they in turn were His people. The idea of covenant did not exercise the same hold over all generations of Jewish faithful as they sought to articulate their relationship with God. This is noted first and foremost in the significant decline in the use of the term in later literature. Already rabbinic Judaism shows far less interest in

\section{Sam 18,3 .}

10 Gen. 21,32; 31,44-46.

11 The Bible also provides an alternative model. Solomon makes a covenant with Hiram, king of Tyre. See 1 Kings 5,26. It may be, then, that the prohibition was in the first instance limited to the nations of the land of Israel and not to others. Alternatively, and to the extent that Solomon's covenant is normative, other criteria, be they diplomatic, political or relating to other circumstances particular to Solomon's time, may have led to affirmation of the possibility of legitimate covenants with neighboring peoples.

12 This is best captured in W. Eichrodt, Theology of the Old Testament, vol. 1, London, SCM, 1961. 
the term and in the concept, having almost abandoned it completely. ${ }^{13}$ It is a matter of conjecture and speculation as to why that might have been the case. One possibility, and one that I personally favor, refers to the fragility of the covenant. The category contains in it its own constant undermining, as it is vulnerable to Israel's disobedience and the possible loss of their status and special relationship. Later generations, especially following the destruction of the first Temple, would seek to place Israel's relationship with God on a much firmer foundation.

For nearly two millennia the idea of the covenant lay dormant. Of course, it never fell into disuse, because the Bible kept nourishing religious language, imagination and practice. This has been the situation for hundreds of years, until the 20th century. There has been a significant rise in the use of covenant in 20th century Jewish thought. For many contemporary Jewish religious thinkers, covenant provides the framework for understanding Judaism. The reemergence of covenantal thinking finds expression in different streams of Judaism, certainly in reform, but also among Orthodox thinkers, such as David Hartman and Irving Yitz Greenberg. The return to covenantal thinking features certain elements in the biblical thought structure. Others do not receive much attention.

Covenant metaphors are one area that has not received much contemporary theological attention. In part, this is related to fundamental changes in the theological challenges that face us today and those that faced biblical authors. The covenant, as noted, is based on polytheistic foundations. Allegiance to the covenant is a allegiance to God, over and against other gods. The situation of competition between gods is no longer relevant. For the most part, other gods have given way to other religions that appeal to the same God. Still, the question of the same God is not all that obvious. Much depends on how Judaism views other religions. To the extent that another religion is still viewed as idolatrous, the competitiveness implied in the covenantal situation could still be relevant. Some Jewish authorities consider Christianity to be idolatrous. The same is true of Hinduism. However, with reference to both religions, we also find authorities that affirm the different religions worship the same God, thereby making the difference one

13 See W.D. Davies, The Gospel and the Land: Early Christianity and Jewish Territorial Doctrine, JSOT Press, Sheffield, 1994, pp. 107-8; Joseph Bonsirven, Le Judaisme Palestinien, Paris, 1934, Vol. 1, p. 79 ff. Compare Reuven Kimelman, The Rabbinic theology of the Physical: Blessings, Body and Soul, Resurrection, and Covenant and Election, The Cambridge History of Judaism, vol. 4, ed. S. Katz, Cambridge University Press, Cambridge, 2008, p. 996. 
of religions, rather than of deities..$^{14}$ Metaphors of covenantal exclusivity could continue operating unchanged if one considers that other religions worship other gods. However, if some, or most, or all religions worship the same God, how do we handle covenantal metaphors?

One theoretical possibility is to ignore them, in the same way that covenantal theology has been ignored for millennia. The modern return to covenantal theology does not imply a return to all the theoretical assumptions of the biblical worldview. Return to the covenant is perforce selective, in line with contemporary needs. If so, some aspects of covenantal thinking receive attention and elaboration, while others are ignored. Covenantal metaphors, if they are no longer applicable, would accordingly be part of the discarded meaning of covenantal thinking.

One possible solution could have been to shift the metaphors from God to the religion. That, however, comes with a heavy price-tag, that borders on the idolatrous. One does not marry a religion or accept the yoke of a religion upon oneself. A religion cannot replace God in a relationship.

There is a further problem with this approach. Most of the proponents of covenantal thinking are also proponents of religious pluralism. While there is no inherent relationship between the different concerns, the fact is that theoreticians who marshal a return to covenantal thinking are part of a modern or contemporary worldview. Whatever needs are addressed by appeal to "covenant" as a theological category, these needs exist alongside other theoretical needs, and these include religious pluralism, that affirms the validity of other faiths and spiritual paths. ${ }^{15}$ Moreover, if the covenant speaks a language of religious exclusivism, its very language and the way it is expressed through metaphors could still feed attitudes to other religions in ways that are the opposite of what the champions of

14 See A. Goshen-Gottstein, Do We Worship the Same God? Jews, Christians and Muslims in Dialogue, ed. M. Volf, Eerdmans, Grand Rapids, MI, 2012, pp. 50-75. See also A. GoshenGottstein, Same God, Other god: Judaism, Hinduism and the Problem of Idolatry, Palgrave, New York, 2016.

15 The work of Irving Greenberg is typical. He is a champion of covenantal thinking as well as of religious pluralism and seeks to accordingly cast the very notion of the covenant in line with the reality of other religions - Christianity and Islam - hat worship the same God. See Irving Greenberg, For the Sake of Heaven and Earth, Jewish Publication Society, Philadelphia, 2004. While Greenberg operates with both theological dimensions, he does not explore covenantal metaphors as part of his opening up of the covenant to the reality of others. For him the covenant itself is a metaphor. 
the covenant would wish. There is a need, therefore, to consider how certain parts of covenantal thinking, and in particular covenantal metaphors, could function once the theological challenge has shifted from viewing other gods to viewing other religions that worship the same God. This, then, is the challenge of the present reflective exercise.

\section{Doing Theology Through Metaphors or How Metaphors Operate}

Metaphors, like parables, are literary tools. As such, they lack precision, if precision is measured by philosophical or theological formulations. There will always be something suggestive in a metaphor, something that transcends the literal meaning. God is not literally husband, father, king etc. And yet, there is something real in how metaphors work and how they condition our religious imagination and our theological thinking. Either the emotions generated by the metaphor are real, or the attitude and relational positioning is, or in some other way the metaphors unreality is complemented by a dimension of its reality.

The parameters of where a metaphor is real and where it is unreal may shift over time. God as father and Israel as son may have been purely metaphorical in the first instance. For later kabbalists they became real. ${ }^{16}$ Similarly the marriage metaphor may be understood in varying degrees of reality and metaphoricity. The point, then, is that the uses of the metaphor are not fixed. They are not established once and for all. The internal life of the metaphor is such that it invites changes over time. These changes are due to internal dynamics as well as to changing conditions, shifts in theological views and more.

What metaphors, and other literary devices, do to theological thinking is to introduce an element of imagination into the discourse. Applying a metaphor is always a projection of imagination into a domain that is characterized by an understanding of something real. The relationship with God is given as something real. Metaphors condition how we view it and how we attune our internal orientation in relation to it. As it is applied, the boundary between real and imaginary, between literal and metaphorical, is stretched and redefined. The metaphor may only orient our attitude, or it may reshape the "real", the given that it is addressing. Because metaphors are, by definition, not real, they can be adapted, their

16 See, for example, Zohar 3,24b. 
meaning changing at different historical points. Application of a metaphor, what we draw from it and how we project it upon the fundamental reality it describes, in this case the relationship with God, is an active process, often a conscious process. The person applying the metaphor, or the parable, projects upon that which is described another order of meaning, by means of which a new understanding, attitude and feeling are established.

Metaphors, then, are dynamic. Far from capturing one thing at a given time, they have the potential to shape and reshape our attitudes and understandings. Metaphors, in this understanding, can serve as theological building blocks, as we seek to articulate new theological statements, or as we adapt old theological statements to new historical or theological circumstances. Paul Ricoeur speaks of the "decontextualization" of the metaphor, which opens it to new meanings, under changed circumstances. ${ }^{17}$ Unlike Jeremias, who sought to read parables in line with the original historical context, Ricoeur considers a process wherein we keep open "the horizon for reinterpretation appropriate to new times and new places. ${ }^{18}$

Here is our challenge, then: How do we work with parables of the covenant under changed historical circumstances? What is the horizon for interpretation appropriate for a covenantal view that seeks to also uphold religious pluralism? How can covenantal metaphors be adapted to a situation in which multiple religions appeal to the same God? These questions require creative application of covenantal metaphors. What follows is my own attempt at tackling this challenge. I am tempted to say - here is my attempt at playing with these ideas, inasmuch as conscious application of a metaphor to changed circumstances does require playing with ideas, in an attempt to uphold religious language, while conveying through this language new horizons of meaning.

\section{Working With Metaphors of the Covenant}

Let us consider the different covenant metaphors and how they might be applied to changed theological circumstances.

17 Paul Ricoeur, Paul Ricoeur on Biblical Hermeneutics, Semeia 4, 1975. See further Paul Ricoeur's "Biblical Hermeneutics" in: T. Oldenhage, Parables for Our Time: Rereading New Testament Scholarship after the Holocaust, Oxford University Press, 2002, Chapter 10, pp. 115-123.

Oldenhage, p. 135. 


\section{The Marriage Metaphor}

The marriage metaphor is arguable the most basic metaphor. Already its biblical usage is partial, suggesting how usage can draw on some aspects that are implied in the metaphor, while ignoring others. The metaphor seeks to affirm loyalty and to express love. The metaphor is applied to Israel as the female partner in a love relationship. Israel's lack of faithfulness is expressed as the woman's covenantal infidelity. ${ }^{19}$ Nothing is ever said regarding the exclusive faithfulness of the divine biblical husband. His faithfulness is measured through continuing care and provision for his wife. But can he have more than one wife? The Bible is silent on this matter, simply because it is of no interest to it. The working assumption is that God is known only to Israel and therefore reflection on this theoretical possibility is pointless. We recall that the basic social reality is polygamous, where exclusive fidelity is only demanded of the wife. If so, there is no theoretical obstacle to God having other "wives", other peoples and other religions who know him. Some few biblical passages consider such a possibility, but never in relation to the covenantal metaphors. ${ }^{20}$ The question is much more acute today, perhaps thousands of years later when such prophecies have been fulfilled. Other nations, or other religions, call God's name. Our interreligious efforts occur at a point in time where derision and mockery of the other have given way to the attempt to understand the religious other and to recover the deeper truths and even the affirmation of the same God in another religion. Under these conditions, one obvious move is to resort to the polygamous potential of the marriage metaphor. God can have more than one wife!

The solution is clearly unsatisfactory emotionally. The expression of the marriage metaphor in the Song of Songs makes a point of highlighting a special relationship. A polygamous God who relates to all religions through the same lens of marital relations will eventually lead to religious relativism and loss of interest in all that a particular relationship can bring the faithful. Choosing metaphors, then, is not only about their applicability. It is also about how they work and how satisfying they can be of religious needs.

The Song of Songs does have a solution. It is cognizant of other women, but affirms a special relationship. Others are concubines or have another status. ${ }^{21}$ Simi-

\footnotetext{
19 See Ezekiel 16; Hoseah 1.

20 See Isaiah 19,25.

21 Song 6,8.
} 
larly, the rabbis extend the metaphor to describe how prophecy works among the nations. God speaks to prophets of the nations just like a king who, secretly, visits his concubines. ${ }^{22}$ Strictly speaking, then, the marriage metaphor could work under changed circumstances and requires very little manipulation. However, the price of adapting its use may be too high. Much that the metaphor sought to convey in the first place would no longer be communicated. It is no accident that the afterlife of the biblical metaphor is found in kabbalistic literature, where the marriage metaphor takes on meanings that are increasingly realistic and nonmetaphorical. But these take place against a background of a religious view of exclusivism that has no room for others, and that in fact considers other nations (and religions) not only not in relationship with God, but actually in relation with the "other side", with the forces of evil. The marriage metaphor was meant to do work in an exclusivist context. Applying it in a pluralist context is only likely in a very evocative and emotional sense, while avoiding any significant extension of its actual content and application to changed circumstances.

There is, however, one important consideration that offsets the emotional concerns that would limit the application of the marriage metaphor. As part of how metaphors shift and are adapted to changing theoretical contexts, many of the metaphors of the covenant have undergone a process of individualization. This is particularly true of the marriage metaphor. At its root, the metaphor describes the relationship of Israel as a collective to God, in line with the covenant. Over time, the metaphor's usage has shifted significantly to the realm of the individual. This is noted clearly in the history of commentaries on the Song of Songs. Midrashic commentaries relate to Israel, the bride, as a collective. The Middle Ages see a rise in commentaries that interpret the Song of Songs as a song of love of the soul. The soul is the bride and God is the groom, in one common interpretation. ${ }^{23}$ If so, the same metaphor applies to many people. Me and my next door neighbor can equally speak of ourselves as brides or lovers, without this creating a situation of competition. Exclusivity is significantly diminished as governing

22 Genesis Rabba $74,7$.

23 A classic source where such an individualized reading of Song of Songs is included is Rabbi Shlomo Alkabez' commentary Ayelet Ahavim. It is worth noting that he is also the author of the celebrated synagogual hymn, Lekha Dodi, where the bride metaphor is applied in relation to the Sabbath. Its range of meanings spans collective and individual usage, as does his commentary to Song of Songs. See R. Kimelman, The Mystical Meaning of Lekha Dodi and Kabbalat Shabbat, The Littman Library, Oxford, 2019. 
metaphors are shifted to the realm of the individual. Once such individualization takes place, the distinction between different religions may be less firm. If one thinks of the soul as the bride, there is nothing particularly challenging about the devotee of another religion describing his relationship to God in similar terms. ${ }^{24}$ In fact, we find precisely such usage in Christian, Muslim and Hindu contexts. Can we affirm their usage of the metaphor in this context? And If we are used to a non-exclusive, parallel, use of this metaphor, could we also tolerate its application not only with regard to another person but also with regard to another religion? The difficulty is only emotional, not conceptual. Do prior adaptations of the metaphor allow us to consider its application in ways that are suitable to an interreligious age?

\section{The Kingship Metaphor}

The question is not limited to the marriage metaphor. It relates also to other metaphors, such as the kingship metaphor. To begin with, kingship metaphors might fare better. Kingship is, after all, not only a metaphor for relationship with Israel. It is also part of Judaism's ongoing focus in prayers. The daily prayer service concludes thrice a day with a prayer for God's universal kingship, at the conclusion of the so-called "Aleinu" prayer. This prayer is a good example of the subtle borders between the metaphorical and the real. We recite this prayer as though it was real, not a literary construct. In fact, the very application of kingship to God is an application of a metaphor. This metaphor has become so deeply ingrained in our religious thought that it has lost much of its metaphoricity. In this, kingship may be in a different situation from marriage. Does this make its application more suitable to contemporary situations?

The kingship metaphor is colonial. If its initial meaning sought to capture God's relationship with Israel, the universalistic understanding of God and the hope that he will be the God of all leads to a quest of the King being known by all. We do not have metaphors of a king going on martial conquests that could match the expansion of faith beyond Israel, but the situation is potentially that. More and more people should come to know God and recognize his kingdom.

24 The argument is not full-proof. One could in theory object to the extension of such a metaphor if one held that only Jews have a soul, or a certain kind of soul. More significantly, if the application of a metaphor to the individual is understood as an extension of its application to the collective, this could curb the utilization with regard to other religions. 
This raises interesting possibilities for the application of the metaphor. If people are subjugated by the king, they eventually become his citizens. Does such expansion of kingship mean that others become part of us? The metaphor contains this possibility. Its application might suggest joining the people of Israel as part of such expansion of divine kingship. But such a reading is not suitable to the interreligious situation. To take an obvious case, does Islam fulfill the quest for God being known by others? If it does, then God's kingship extends to Islam. What does this do to the kingship metaphor? Muslims are not God's people in the same way Jews are. They are also not part of the people of Israel. ${ }^{25}$ Can one king have multiple nations whom he subjugates and rules over? In theory yes. But then we encounter, once again, the problem of exclusivity. There is a tension, then, between reference to God as king in a covenantal-metaphorical context and in the more real, though still metaphorical, sense in which it serves the quest for universal knowledge of God. One possible solution would be to underline precisely this distinction. Recognizing the starting point of the kingship metaphor, one would move it from a metaphor of exclusivity to the more realistic realization of God's kingship in different religions. Changing circumstances would then lead to keeping the metaphor but shifting the boundaries of its application from the metaphorical to the more real (though still metaphorical) and from the exclusive to the universal.

There might be another way of applying the kingship metaphor. There are two complements to king - people and servants. The previous discussion focused on the relationship of king and people. But what of king and servants? A king (or master) can have multiple servants. From the perspective of the dedicated focus of the servant, there is no problem in other servants sharing the task and responsibilities of serving the king. In fact, the glory of the king lies in his having multiple servants. If so, profiling being servants of God could allow us to overcome the problem of exclusivity of relationship, inasmuch as the servant relationship is never really imagined as one of exclusivity. Alternatively, king and people could capture Israel's relationship, while king and servant could capture a universal reality.

25 One thinker who is sensitive to this problem is Yitz Greenberg, who draws radical conclusions from this conundrum. See For the Sake of Heaven and Earth, extending Israel's peoplehood to these religions. 
Rabbinic metaphors introduce another figure alongside the servant - the son. Rabbinic parables play out the relationship of servant and son in interesting ways. ${ }^{26}$ The rabbis recognize that one metaphor cannot capture the entire range of a relationship. One is therefore both a son and a servant. Circumstances change. At times one is a son, at others a servant. Extending this recognition to the present exercise, we may consider that other religions may join in role of the servant. Special relationship may be communicated via the metaphor of the son. Much depends on what we seek to achieve. Cultivating metaphors of full equality is a different challenge than opening up metaphors to make room for others while continuing to affirm Israel's special status. King, people, son and servant open up a range that allows us multiple combinations, to suit different theological temperaments.

\section{The Parental Metaphor}

Let us extend this to a consideration of another metaphor, that of parents. The metaphor seems particularly well-suited for the interreligious situation. A parent can have more than one child. Each child enjoys a special relationship with his parent(s). While sibling rivalry is a fact of family relations and a feature of biblical narrative, the ideal metaphor does leave room for imagining a harmonious family relationship where multiple siblings receive appropriate love from their parents. The Bible already offers us a strategy for maintaining Israel's special status, within such a view of a family. The sole biblical reference to Israel as God's first born (Ex. 4,22) suggests that alongside the first born there are other children. It is noteworthy that so little is made of this metaphor in the Bible itself. But that is precisely the point. There is no need to feature other children in terms of what biblical theology seeks to express. That is the very need that has arisen since. ${ }^{27}$ With growth in universal thinking and with the rise of other children - religions that call God's name, we must find a way of speaking of these. The family metaphor is promising not only because it makes room for other children, while maintaining Israel's special relationship. It also establishes relations between the

\footnotetext{
26 See A. Goshen-Gottstein, God and Israel, pp. 162-175.

27 This need can only be satisfied on the level of metaphor. Sonship is one metaphor that has moved in various religious understandings from the metaphorical to the real. This is obviously the case in Christianity. But there are many expressions of the same movement in Judaism. See Moshe Idel, Ben: Sonship and Mysticism, London-New York, Continuum, 2007.
} 
siblings in line with the covenantal model. The one reference to God as father, in covenantal terms, takes into account the ways in which this metaphor functions both horizontally and vertically. "Have we not all one father? hath not one God created us? why do we deal treacherously every man against his brother, by profaning the covenant of our fathers?" ${ }^{28}$ Because we have one father we must also treat each other as brothers. All this, in the framework of the covenant.

Let me add a word from experience regarding the application of this verse from Malachi in an interreligious situation. Appeal to metaphors is intuitive. While we need to give consideration to what metaphors we use and how we apply them, there remains something intuitive, even spontaneous, in the metaphors we chose. Against the background of this recognition, I recall a moment in 2003 in Seville, Spain. The situation was the founding of the Elijah Board of World Religious Leaders. The group convened featured high ranking religious leaders from all world religions. In the palace of Seville's Cardinal, the Chief Rabbi of Israel, Shlomo Amar, offered a brief homily. He referred to different religions citing Malachi 2,10. For him, the appeal to a common divine paternity was not only theoretically possible; it also allowed for featuring human fraternity, as children of the same God. If the covenant offers us several metaphors, this one may work particularly well, even if it is not central to the biblical outlook. Metaphors need to be chosen in line with the work they do and the circumstances they address. If so, a metaphor that was marginal to covenantal thinking (though not necessarily to other aspects of biblical thought) could gain prominence under other circumstances, moving from the periphery to the center.

While both marriage and paternity could uphold special relationship alongside recognition of the other, contemporary sensibilities would suggest a preference for the family metaphor. A polygamous metaphor is foreign to contemporary sensibilities, even if in theory it could work. Before metaphors can be made to work for present-day concerns, they have to ring true and to be recognized as real life situations that can serve as a springboard for theological understanding.

Like the marriage metaphor, the parental metaphor too suffers from limited application. We have two parents, yet most of biblical thought focuses on the father, not the mother. ${ }^{29}$ Once again, later generations have filled in the gap. With the rise of kabbalistic thought, the mother figure has come to the fore. Could the

28 Malachi 2,10.

29 For references to God as mother, see Isa. 66,13 and more. 
figure of the dual parents be helpful in an interreligious situation? Could Israel, for instance, share only one parent with the rest of humanity? If the mother is the creative divine force in charge of all creation, could Israel share the divine mother, while enjoying a special relationship with the father? Or vice versa, could God the creator father be relevant to all, while the mother, the shekhina is particularly identified with Israel? ?0 $^{30}$

\section{The Shepherd}

All the metaphors discussed above relate to the covenant. There are other metaphors that do not draw on the covenant and that may also be relevant to the present exercise. One important way of talking of God is as a shepherd. God is our shepherd and we are his sheep. Unlike earlier metaphors that capture our responsibility and allegiance to God, shepherd/sheep functions are more one sided. It only expresses God's care and provision. If we are sheep, what are other nations (and religions?). Typically the answer is - wolves. The sheep are menaced by the wolves, the nations, and are protected by the shepherd. Shifting the metaphor would lead us to the domain of God's universal care. God does not only care for us. He cares for all of creation. Historically, others have been viewed as our enemies, out to destroy us. In some ways, that still rings true today. But there is also another reality, where we and others share in God's care for creation. There is something inoffensive in relating to other religions as another flock or as sheep in the same flock, enjoying God's care. If we are sheep, all is divine grace, love and providence. We cannot complain that other sheep are receiving God's care just as we should not complain that the king has other territories that recognize his kingship.

\section{The Metaphor of Friend}

One last metaphor I would like to consider is that of the friend. Like "king", "friend" is less of a pure metaphor, and crosses the boundary between metaphor

30 These two metaphors have been suggested as a way of approaching the contemporary challenges of multiple religious belonging. Belonging to two religions would be like having a father and a mother. One receives something different from each and grows from both. See Abraham Vélez de Cea, An Alternative Conception of Multiple Religious Belonging: A Buddhist-Catholic Perspective, Buddhist-Christian Dual Belonging: Affirmations, Objections, Explorations, ed. Gavin D'Costa and Ross Thompson, Ashgate, Farnham, 2015, pp. 161- 178. 
and reality. One can describe God as friend as a way of affirming a relational quality that is not necessarily metaphorical, but that is felt as real. At the same time, to speak of God as friend is also metaphorical. After all, awareness of God as friend is interior and subjective, drawing on the imagination and thus on the interiorized metaphor of the friend, made real in subjective awareness. Unlike family, or even kingship, friendship is not something one is born into. It is chosen. It is therefore particularly well suited to an understanding of covenant as something formed by choice, in a voluntary way. ${ }^{31}$

There are advantages to applying the friendship metaphor. Like the family metaphor, it can work both horizontally and vertically. One is friends with God. This suggests sharing, caring and a mutuality in addressing each other's needs. It also undermines hierarchy, a quality that characterized all other metaphors. ${ }^{32}$ The metaphor has much versatility in that it can be applied with the same elasticity that characterized the application of the very notion of friendship. ${ }^{33}$ One can have close and distant friends. One does not make covenants with all friends. Thus, there are friends with whom one makes a covenant and others that are noncovenanted friends. One can thus relate simultaneously to Israel and to the nations, while affirming the special status of other religions as friends. Friends thus has the advantage that it allows us to capture special relationships with God. One can have a special friend, while having many other less "special" friends. And specialness of friendship could be pitched at various levels. While the metaphor may be pitched broadly, referring to Israel or to all members of a faith as friends, it is particularly well suited to capture the special relationships of individuals who are close to God and who are therefore called "friends of God". ${ }^{34}$

31 Initially between people, but possibly also in relation to God. Actually, the biblical covenant assumes voluntary foundations that inform the act of making it. This is well illustrated in Mechilta Bahodesh 5. However, once the covenant has been made with the people, this choice is no longer operative. In theory, the marriage metaphor also describes a love freely given. However, social circumstances do not profile this potential dimension of the metaphor.

32 Even the marriage metaphor assumes some hierarchy, even if at its height it seeks the reciprocity of love, as found in the Song of Songs. Its polygamous foundations preclude total elimination of hierarchy.

33 On the elasticity of friendship, see A. Goshen-Gottstein, Understanding Jewish Friendship, Extending Friendship Beyond Judaism, in: ed. A. Goshen-Gottstein, Friendship across Religions: Theological Perspectives on Interreligious Friendship, Lanham, Lexington Books, 2015, pp. 1-35.

34 See J. Renard, Friends of God: Islamic Images of Piety, Commitment and Servanthood, University of California Press, Berkeley, 2009. 
The friend metaphor also has an important horizontal dimension. Not only does God the friend have many friends. That he has friends means that we too can have friends and these can be from among his friends, in other words - members of other faiths. Friendship, then, can function as a comprehensive metaphor, addressing simultaneously multiple relationships, affirming special relationships, and opening up relational fields both horizontal and vertical.

Metaphors could be combined in order to convey complex relationships. God may have many friends, but only one wife. This corresponds to our own emotional reality, where a particular relationship finds expression without sacrificing the possibility of other, less charged, relationships. Friendship can affirm religious pluralism, while existing alongside other metaphors that profile special relationships.

While the metaphor of God as friend is itself not a covenantal metaphor, the notion of friendship is tied to covenantal thinking. We have noted how one type of biblical covenant is the covenant between friends. This is made in God's presence, and creates a three way relationship between the two human parties and God. It is interesting and maybe even significant that the friendship covenant does not translate into one of the biblical metaphors for Israel's covenant with God. Perhaps this leaves it open to the kind of development suggested here. Perhaps we have here a part of the biblical covenantal complex that was not applied to the relationship with God and whose time has come. It is possible that friendship conveys aspects of covenantal relationship that are more suitable to the concerns of interreligious theology than other metaphors.

This brings us back to the concern of the biblical prohibition on covenantmaking. Should the biblical prohibition limit our willingness to apply friendship in relation to other religions, as an expression of a covenantal approach? I think the answer hinges largely on the Same God issue. The gods of Canaan were understood as other gods. This, in turn, served as a limiting factor in forming relationships with the people, which one way or another would have implication for their gods, either as partners to the covenant or as threatening realities that would remain a menace in view of the covenant. The present exercise is being carried out on "Same God" premises. If so, also the concern for extending friendship, covenantally, across religions, would not apply to religions that call on the same God. On the contrary, friendship is founded on some combination of similarity and difference. If the brother is like me, the friend is in some ways like me, in 
other ways unlike me. This describes perfectly the situation of the other religion that calls the name of the same God. Brothers do not conclude covenants; friends do. This provides then the perfect context for making a covenant with another religion as such a friend.

What such a covenant would mean is the affirmation of friendship as a three way process, engaging as witness, as guarantor and as source of inspiration and presence, the one God common to both faiths, to both friends. It invites learning and inspiration as points of sharing between friends. And it invites joint commitment, in covenantal light, to concerns of the third party, God. These may be the spread of justice and charity in the world, care for creation or any common concern that unites the two friends, in the presence of the third covenanted party. ${ }^{35}$

The idea that emerges, then, is of the possibility of applying covenantal thinking, following the model of friendship, to relations between religions. I raise this idea not only as a theoretical possibility but also by way of a practical initiative. I have been involved in the drafting of a declaration of friendship between religions, following a very successful public message of friendship between religions, issued by premier faith leaders of all major religions. ${ }^{36}$ Going beyond the call of friendship to believers of religions, we can consider what would a call for friendship between the religions themselves look like. Here the notion of covenant emerges as one interesting possibility. Deliberations on this subject suggested one way of presenting the notion of friendship between religions in covenantal terms. To me, this indicates the promise of this metaphor and the rich ways in which it can be upheld, adapted and applied to the contemporary interreligious situation.

\section{Conclusion}

In one way, working with a metaphor is intuitive. We have seen one example of that above. But it is also something that requires conscious application and analy-

\footnotetext{
35 Another metaphor that could work in multiple directions is the metaphor of the teacher. God is a teacher, and as such he can teach all. Some students have a special relationship with their teacher, creating a distinction between the special teacher and other teachers. God as teacher may have general and particular relationships. Teaching could also function horizontally in relation to other people (religions) who in turn also have what to teach us, possibly drawing from the source of the common teacher, through parallel teachings. The teacher metaphor goes beyond the metaphors common to abrahamic faiths and provides common ground with Eastern faiths.

www.youtube.com/makefriends
} 
sis. This is all the more the case when we return to metaphors that have not been applied for a very long time, or that have been applied without due consideration to the full baggage they carry or to the changing contexts within which they are applied. We face significant theological and educational challenges. We seek to keep alive a tradition of hoary antiquity and to apply its message and its language to changing circumstances. The change between an exclusivist view of other religions, where only one's own religion knows the true God, and a pluralist context, in which other religions are seen as worshipping the same God, is a radical one. It requires thoughtful and self conscious application of religious language, theological categories and literary-conceptual tools such as the metaphors we have discussed.

Something of the spontaneity associated with metaphors may be lost. But perhaps metaphors were not all that spontaneous in the first instance. Metaphors were chosen with some point in mind, some context they serve, some lesson they convey, while silencing or ignoring other aspects that reside in the metaphor and do not reach full articulation. There is a fine dance in continuing to apply the language of old and addressing radically changed theological circumstances. This dance requires thoughtful consideration and application of literary devices. It also calls for a considered aesthetic and emotional response. The exercise I have shared is an invitation to think of what can work and how we can apply metaphors to ideas and ideas to metaphors. But it is also an invitation to engage aesthetically and emotionally with materials that have been with us for the longest time and that we often put aside or do not make full use of. It is thus an invitation to engage the mind and the imagination in the process of evolving religious thought and theological creativity. I can think of few people who represent harmoniously the coming together of mind and imagination in the service of theological thinking as does Staszek Krajewski. It is therefore a joy and privilege to share these reflections in his honor.

\section{Bibliography}

Bonsirven J., Le Judaisme Palestinien, Paris, 1934, Vol. 1.

Davies W.D, The Gospel and the Land: Early Christianity and Jewish Territorial Doctrine, JSOT Press, Sheffield, 1994. 
Eichrodt Walther, Theology of the Old Testament, Vol. 1, SCM, London 1961.

Gerson C., The Song of Songs and the Jewish Religious Mentality, Jewish Theological Society, New York 1966.

Goshen-Gottstein A., God and Israel and Father and Son in Tannaitic Literature, Phd, Hebrew University of Jerusalem, Jerusalem 1986 [Hebrew].

Goshen-Gottstein A., God between Christians and Jews: Is it the same God?, in: Do We Worship the Same God? Jews, Christians and Muslims in Dialogue, ed. Volf M., Eerdmans, Grand Rapids, MI 2102, pp. 50-75.

Goshen-Gottstein A. (ed.), Judaism's Challenge: Election, Divine Love and Human Enmity, Academic Studies Press, Boston 2020.

Goshen-Gottstein A., Korn E. (eds.) Jewish Theology and World Religions, Littman Library, Oxford 2012.

Goshen-Gottstein A., Same God, Other god: Judaism, Hinduism and the Problem of Idolatry, Palgrave, New York 2016.

Goshen-Gottstein A., Understanding Jewish Friendship, Extending Friendship Beyond Judaism, in: ed. A. Goshen-Gottstein, Friendship across Religions: Theological Perspectives on Interreligious Friendship, Lexington Books, Lanham 2015, pp. 1-35.

Greenberg I., For the Sake of Heaven and Earth, Jewish Publication Society, Philadelphia 2004.

Idel M., Ben: Sonship and Mysticism, Continuum, London-New York 2007.

Kimelman R., The Mystical Meaning of Lekha Dodi and Kabbalat Shabbat, The Littman Library, Oxford 2019.

Kimelman R., The Rabbinic Theology of the Physical: Blessings, Body and Soul, Resurrection, Covenant and Election, in: ed. Katz S.T., The Cambridge History of Judaism, Vol. 4: The Late Roman-Rabbinic Period, Cambridge University Press, Cambridge 2006, pp. 946-976.

Kimelman R., The Shema' Liturgy: From Covenant Ceremony to Coronation, in: Kenishta: Studies of the Synagogue World, ed. J. Tabory, Bar Ilan University Press, Ramat-Gan 2001, pp. 9-105.

Oldenhage T., Parables for Our Time: Rereading New Testament Scholarship after the Holocaust, Oxford University Press, Oxford 2002.

Renard J., Friends of God: Islamic Images of Piety, Commitment and Servanthood, University of California Press, Berkeley 2009.

Ricœur P., Crossan J.D., Dornisch L., Paul Ricoeur on Biblical Hermeneutics, "Semeia" 1975, Vol. 4. 
Vélez de Cea A., An Alternative Conception of Multiple Religious Belonging: A Buddhist-Catholic Perspective, in: Buddhist-Christian Dual Belonging: Affirmations, Objections, Explorations, eds. G. D'Costa, R. Thompson, Ashgate, Farnham 2015, pp. 161-178.

Vriezen Th.C., Theologie des Alten Testaments in Grundzeugen, Wageningen 1965.

\section{Summary}

Religious thought does only express abstract truths. It also captures relationships and these are served by means of metaphors. Metaphors condition the religious imagination as well as theological thinking. One of the key concepts of biblical faith is the covenant between God and Israel, itself a crossover between a literal and a metaphorical view of the relationship. The covenant is served by a series of metaphors - husband/wife, king/people, parent/child, shepherd and more. Covenantal metaphors took shape in a context in which Israel alone was considered to have a valid relationship with God. Historically, there has been a decline in covenantal theology for two millennia, since the end of the period represented in the Hebrew Bible. The twentieth century witnessed a revival of Jewish covenantal theology. Proponents of such a theological view happen to also be proponents of religious pluralism in relation to other faiths. This presents an interesting challenge that has not been previously tackled. How does one apply the biblical covenantal metaphors, that came into being during a period of religious exclusivism in an era of religious pluralism? Such application must be deliberate, and may lack some of the spontaneity associated with the uses of metaphor. The present essay considers the metaphors above and how they might be expanded and reinterpreted in the context of interreligious pluralism. It also considers the metaphor of the friend, which in and of itself is not one of the stock biblical covenantal metaphors, and its usefulness for the present theological challenge. The metaphor of the friend allows us to develop a contemporary religious approach that can function both vertically, in relation to God, and horizontally, in relation to other peoples and religions.

Key words: metaphors, covenant, Paul Ricoeur, religious imagination, Song of Songs, divine kingship, friendship, pluralism, interreligious dialogue 


\section{Streszczenie}

\section{Metafory przymierza i rzeczywistość międzyreligijna}

Tezy religijne odnoszą się jedynie do prawd abstrakcyjnych. Uchwytują też relacje, które przedstawiają za pomocą metafor. Metafory warunkują wyobraźnię religijną oraz myślenie w kategoriach teologicznych. Jednym z kluczowych aspektów biblijnej wiary jest przymierze zawarte między Bogiem i Izraelem, które rozumiane być może zarówno literalnie, jak i metaforycznie. Wspomniane przymierze opisywane jest przez szereg metafor - mąż/żona, król/poddani, ojciec/dziecko, pasterz i inne. Metafora przymierza ukształtowała się w kontekście, w którym Izrael miał wyłączność na posiadanie istotnej relacji z Bogiem. Od czasu, w którym kończy się historia przedstawiona w hebrajskiej Biblii, czyli przez ostatnie dwa tysiąclecia, daje się zaobserwować zanik teologicznych rozważań o przymierzu. Dwudziesty wiek jest jednak czasem, kiedy żydowska teologia przymierza przeżywa powtórny rozkwit. Akurat tak się zdarzyło, że zwolennicy takiego teologicznego podejścia odznaczają się również przychylnym nastawieniem do pluralizmu religijnego $\mathrm{w}$ stosunku do innych wiar. To stawia przed nami interesujące wyzwanie, które nie zostało wcześniej podjęte. Jak można zasadnie posługiwać się biblijną metaforą przymierza, która sformułowana została w czasach ekskluzywizmu religijnego żydów, w czasach religijnego pluralizmu? Używanie tej metafory musi być celowe i może mu brakować czegoś ze spontaniczności, które związane jest z posługiwaniem się metaforami. Niniejszy artykuł skupia się na przytoczonych wyżej metaforach i na tym, jak mogą być one poszerzone i zreinterpretowane w kontekście pluralizmu międzyreligijnego. Kolejną ważną metaforą, na której koncentrują się rozważania prowadzone w artykule, jest metafora przyjaciela - która sama w sobie nie jest częścią biblijnych metafor przymierza - oraz jej przydatność dla współczesnych wyzwań teologicznych. Metafora przyjaciela pozwala nam rozwinąć religijne podejście do relacji z Bogiem ( $w$ formie wertykalnej) oraz do relacji z innymi ludźmi i religiami (w formie horyzontalnej).

Słowa kluczowe: metafora, przymierze, Paul Ricoeur, wyobraźnia religijna, Pieśń nad Pieśniami, Królestwo Boże, przyjaźń, pluralizm, dialog międzyreligijny. 